\title{
REVIEW
}

Rights

\section{Moli Paul}

Arch Dis Child 2007;92:720-725. doi: 10.1136/adc.2005.091629

This article provides an overview of different types of rights to aid consideration of, and debate about, children and young people's rights in the context of paediatrics and child health. It demonstrates how children's rights may or may not differ from adult rights and the implications for practice. It shows that applying a children's rights framework can be more helpful in pursuing a public child health agenda than in reducing ethical or legal conflicts when interacting with child patients and their families.

Correspondence to:

Medical S'chool, Gibbet Hill,

University of Warwick,

Coventry CV4 7AL, UK;

moli.paul@warwick.ac.uk

Accepted

12 December 2006
C hildren's rights are being discussed both in clinical deliberations about individual children and at professional, healthcare delivery and political fora in relation to meeting the needs of children as a group. Children's rights are not however a unitary concept. Meaningful dialogue requires clarification of the type of rights being discussed, their justification and specification of who holds the resulting duties.

In general, rights can be understood in terms of what they assert about human relationships and human action. ${ }^{1}$ They may flow from:

- the law (legal rights),

- the way things are usually done in society (socio-cultural rights), and

- our status, for example as citizens (political rights) or individuals worthy of moral consideration (moral rights).

These different types of rights frequently coexist.

In addition, different types of rights may share similar categories because of a common justification raised by a particular theory. For example, Utilitarianism is a theory that can propose that a person ought to choose because individual choice maximises human happiness. Maximising human happiness therefore justifies respecting choice, creating a right to choose (a category of rights). The right to choose is relevant when considering many types of right, for example legal, political and moral rights. Similarly, any type of rights, if conferred by virtue of our common nature or humanity, falls under the category of human rights.

Justifications are important when we consider why clinicians should respect, prioritise, promote or protect any particular children's right because different justifications lead to different actions, as exemplified in table 1. Different justifications are also important when we consider whether children have the same rights as adults (see below). Retaining the distinction between
- types (relevant to different contexts) and

- categories (created by different justifications)

of rights promotes clarity of reasoning when using rights to decide what to do in a clinical situation.

Different people's rights have to be balanced in any particular situation, for example a child's and his/her parents' individual rights in relation to decision-making about the child's treatment. ${ }^{2}$ Parents may hold rights:

- on behalf of their children, as proxy decisionmakers or legal representatives,

- as parents, because of the importance of family integrity within liberal societies,

- as those legally responsible for children, ${ }^{3}$ or

- as individuals, due respect for private and family life. ${ }^{4}$

An individual has different rights which ought to be balanced, for example a child's rights to protection and to choose. If a 14 year old abused child chooses to live with her abusive parent, knowing the risks and having the option of living with another parent/carer, the clinician must decide which category of rights to prioritise.

Rights can also be considered alongside other legal, political, social, cultural and ethical principles and imperatives. For example, when considering the ethics of treating a child, clinicians may consider their patient's rights; an alternative is to use Beauchamp and Childress' four principles of non-maleficence (avoiding doing harm), beneficence (doing good), respecting autonomy and justice. $^{5}$ For parents in this situation, acting out of love is likely to be a more common reason for permitting treatment than meeting the child's right to medical care. ${ }^{6}$ Whether using a rights or four principles framework, a clinician's justification for the action taken (eg, accepting the child's choice) may be the same, as many of the theories (eg, Utilitarianism) that give rise to moral rights also give rise to the four principles. Thus, a rights framework gives paediatricians an alternative way of reasoning about their child patients in moral, legal and socio-cultural contexts, but may not lead to paediatricians changing what they do.

Paediatricians' reasoning about what to do in interactions with patients are further complicated by the number of contemporaneous roles relevant to clinical practice, especially within the National

Abbreviations: GMC, General Medical Council; HRA, Human Rights Act 1998; NHS, National Health Service; RCPCH, Royal College of Paediatrics and Child Health; UNCRC, United Nations Convention on the Rights of the Child 
Health Service (NHS). For example, medical professional codes specify "action guides", or principles and rules within a framework of normative ethics. This creates a "role morality" which may or may not promote the same type of behaviour as that required by other relevant bodies, for example the government or employer (table 2).

The duties of a doctor registered with the General Medical Council include imperatives that could be justified by patients' rights, and others which flow from the doctor-patient relationship, professional virtues and etiquette. In Duties of a paediatrician issued by the Royal College of Paediatrics and Child Health $(\mathrm{RCPCH}),{ }^{8}$ the first stated duty of paediatricians is to "...commit themselves to practice in accordance with the Objects of the College and the UN Convention on the Rights of a Child". Children's rights are therefore at the heart of this paediatric action guide. The RCPCH Duties are broader in scope and context and include public health and political duties; for example "paediatricians should be aware of current medical and political affairs affecting the lives and health of children" and "paediatricians should serve as advocates for the health needs of children locally, nationally and internationally".

\section{SPECIFIC TYPES OF RIGHTS Moral rights}

There are three main theories of rights ${ }^{5}$ :

- claim theory (rights as justified claims, for example the right to choose justified by the Utilitarian argument that the greatest amount of human good results from the greatest number of people choosing for themselves),

- interest, or benefit, theory (rights flow from essential interests), and

- choice theory (the only natural right is the right to be free).

Generally, moral rights claim something or claim freedom from something. They can be meaningless unless other people have reciprocal duties to meet the claims or interests, or to respect the choices.

Philosophical discussion about children and childhood that does not primarily conceptualise children as incomplete adults, "proto-adults", or extensions of or the property of their parents, mainly dates from the 1970s and the rise of children's rights movements and rights talk (rhetoric using the language of rights). Most philosophers have not directly considered the moral status of children or the implications for the defensibility of their theories ${ }^{10}$ (table 3 ).

\section{Legal rights}

This paper is written in the English and Welsh legal context and readers not practising within this area should consider their own local legal context. In England and Wales, the body of the law consists of common law (a tradition of judge-made law, which began in medieval England), case law (judge-made law expressed in court decisions) and statutory law (parliamentary statutes, and their accompanying administrative regulations, such as codes of practice). Statute generally takes precedence over case law, but there is no hierarchy of statute and revised codes of practice usually take into account case law that followed the statute. Case law can take into account concepts such as "good clinical practice" set by regulatory bodies such as the GMC but need not necessarily do so.

Clinicians should practice within the law, especially statutory law. Although most statutes do not impose a legal duty to comply with their code of practice, failure to comply with their guidance could be referred to in legal proceedings. Case law, by nature, can change at any time, and therefore professionals should keep up to date with the relevant law. Good clinical practice is likely to result from clinical and professional concerns rather than the law.

Within this context, substantive legal rights are enforceable by law and enable the right-holder to take actions affecting others or to resist actions taken by others against them. Procedural legal rights exist to ensure fairness during the judicial decision-making process. ${ }^{11}$

The focus on health-related law has widened over the last 30 years

- from medical law (based on the doctor-patient relationship $)^{12}$

- to healthcare law (based on consideration of health rather than illness, regulation as well as litigation, the obligations of the NHS to provide services and consideration of healthcare professionals as opposed to just doctors $).{ }^{13}$

This reflects a shift from law within which rights were derived from contract to law within which legal rights are based on the status of the individual, for example as a human, citizen, and service user. ${ }^{14}$

Over the last couple of centuries, the legal pendulum has swung between theories that see ethics as relevant to the law and those that do not. ${ }^{14}{ }^{15}$ Such paradigm shifts do not necessarily entail the displacement of earlier law. The law on consent for children's treatment, for instance, still contains case law (derived from contract-based torts) alongside the Children Act 1989 (espousing human rights for children) and the Human Rights Act 1998 (HRA; concerned with the prevention of undue interference by the state with individual freedom). Clinicians working in the NHS, essentially a public authority, must practise in line with the $\mathrm{HRA}^{16}$ and any limitation of patients' rights must be justifiable, appropriate, necessary and proportionate to the right denied. ${ }^{17}$

There is conflicting jurisprudence about whether or not children are rights-holders and if they are, what legal rights they might legitimately demand. ${ }^{18}$ The law considers children and young people under 18 years of age (the age of majority) as minors, because they are assumed to lack capacity, ${ }^{19}$ and effectively withholds the right to adult autonomy in exchange for protection. Minors may have rights to be heard but not to have the last say, as adults do. Minors' rights are more likely to be what relevant adults consider to be in their best interests ${ }^{3}$ rather than rights of self-determination.

Table 1 An example of how applying different rights-related theories can lead to different actions. Question: should a paediatrician respect the right of a 14 year old to refuse treatment?

\begin{tabular}{|c|c|c|c|}
\hline Type of rights & Theory & Justification & Action \\
\hline Moral rights & $\begin{array}{l}\text { Utilitarian } \\
\text { Kantian }\end{array}$ & $\begin{array}{l}\text { A person has a right to choose because individual choice } \\
\text { maximises human happiness } \\
\text { Respect for autonomy, and therefore human autonomous } \\
\text { choice, is the duty of moral persons }\end{array}$ & $\begin{array}{l}\text { Respect the refusal because respecting individual choice } \\
\text { maximises both the child's happiness and collective happiness } \\
\text { Assess the patient's capacity to choose autonomously before } \\
\text { deciding whether to respect the refusal }\end{array}$ \\
\hline
\end{tabular}


Table 2 The contemporaneous roles of paediatricians working within the NHS

\begin{tabular}{llll}
\hline Role & Relationship & Relationship with & Context \\
\hline Doctor & Doctor-patient & Child patient, parent(s)/carer(s) & $\begin{array}{l}\text { Profession-specific } \\
\text { Intervention-specific }\end{array}$ \\
& Therapeutic & Child patient, parent(s)/carer(s) & Organisation-specific \\
& Service provider-service user & Child patient, parent(s)/carer(s) & As a member of a self-regulated profession \\
& Protector-protected & Child & As a member of the RCPCH \\
& Doctor-doctor & Junior and senior doctors & Organisation-specific \\
Employee & Paediatrician-paediatrician & Junior and senior paediatricians & Government agency-specific \\
& Employee-employer & The NHS & Humanity/society \\
Person & Public servant-government & Department of Health & \\
\hline \multirow{2}{*}{ NHS, National Health Service; RCPCH, Royal College of Paediatrics and Child Health. } & \\
\hline
\end{tabular}

The law also conceptualises minors in different ways, for example as victims, "a bundle of needs", or delinquents. ${ }^{20}$ Their capacities and rights within these roles are inconsistent when compared, for example the age of criminal responsibility is 10 years, but children are not assumed to have the ability to consent to medical treatment is until they are 16 years of age.

\section{Political rights}

Political rights have been described as the basic building blocks of the contemporary liberal state but have just as convoluted a history and varied sets of justifications as moral rights. ${ }^{21}$ Some political rights are bound to concepts of citizenship and whether children have this status is questionable.

\section{SPECIFIC CATEGORIES OF RIGHTS Human rights}

The theories that gave rise to "human" rights have informed moral philosophy as well as legal and political philosophy. ${ }^{22}$ Currently, human rights are considered essential to any individual's human dignity. They are:

- inherent (belonging to all humans and not dependent on any other status),

- inalienable (cannot be given up or taken away), and

- universal (applicable to all humans regardless of age, gender, nationality or race) ${ }^{16}$

Universal human rights are set out in documents like the Universal Declaration of Human Rights or conventions such as the European Convention on Human Rights and Fundamental Freedoms. The adoption of such documents by organisations and countries provides practical ways to apply rights theory and rhetoric to national and international politics and law, and personal and professional practice. Terms like "dignity" are, however, ambiguous both in terms of definition and scope.

The philosophical justifications for respecting human dignity are that humans can
- choose purposively and voluntarily or

- engage in moral reasoning.

Defining human rights in terms of respect for human dignity empowers those who can act purposefully as a result of free will (sometimes called moral agents), but also sets limits on their autonomy. As a consequence, some humans, including many children, might not qualify as moral agents.

Ascribing human rights to those who cannot act purposefully as a result of free will (non-agents) is justified by:

- giving those who fulfil only some of the requirements for agency rights proportionate to their agency, and

- giving those who will develop agency, but have current vulnerabilities, rights appropriate to their vulnerabilities and preparatory rights consistent with the goal of achieving agency. ${ }^{23}$

If human rights are universal, then the particular differences inherent in non-dominant groups, such as children, should be taken into account. This is achieved through additional protocols or conventions, such as the United Nations Convention on the Rights of the Child (UNCRC). ${ }^{24}$ Thinking of children as a non-dominant group, with particular differences, also enables human rights considerations to be used in relation to public health concerns about children. Children's rights are primarily promoted by adults in an adult-dominated world, although more children are now claiming rights. ${ }^{25}$ Importantly, although human rights, or equal rights, for children are claimed, few claim all adult rights for children. ${ }^{26}$

\section{CHILDREN'S RIGHTS}

Specific discussion about children's rights started in the 1970s and subsequently rhetoric, theory and research on children and childhood, ${ }^{27}$ parents and parenthood, ${ }^{28}$ and children's and parent's rights ${ }^{26}{ }^{29}$ expanded. Recently this journal published a series of articles ${ }^{30-33}$ seeking to bring "...the concept of children's rights alive for practising paediatricians". ${ }^{34}$ What

Table 3 Theories of moral rights

\begin{tabular}{|c|c|c|c|c|}
\hline & Justification & $\begin{array}{l}\text { Categories of rights } \\
\text { justified by the theory }\end{array}$ & Also known as & Implications for children's rights \\
\hline Claim theory & Rights are justified claims & & & \\
\hline Interest (or benefit) theory & $\begin{array}{l}\text { The essential interests that individuals } \\
\text { require in order to flourish entail } \\
\text { fundamental rights }\end{array}$ & Welfare rights & Positive rights & $\begin{array}{l}\text { Children's rights differ from adults' rights } \\
\text { if children's essential interests } \\
\text { differ from adults' essential interests }\end{array}$ \\
\hline Choice theory & $\begin{array}{l}\text { There is only one natural right - the } \\
\text { right to be free }\end{array}$ & $\begin{array}{l}\text { Rights to self- } \\
\text { determination, } \\
\text { liberty rights }\end{array}$ & Negative rights & $\begin{array}{l}\text { Children only have these rights if they belong } \\
\text { to the status of people who have the right to } \\
\text { be free in all matters concerning themselves }\end{array}$ \\
\hline
\end{tabular}


are children's rights though? Are they different from adults' rights, and if so, why?

\section{Possible differences between adults' and children's rights \\ Terminology}

Children's rights (to protection, provision and participation) are discussed using different terminology (legal, social, economic, political and moral) from adults' rights. This is a reflection of the expansion of the academic study of the sociology of childhood and the seeking of legitimacy and efficacy by the children's rights movement(s). ${ }^{29}$ Children are no longer adults in the making; childhood is now understood as a status (variable, conferred by others, and dependent on others' perceptions and labels) rather than a state (biologically inherent, non-variable, unchangeable). ${ }^{27}{ }^{35}$ Children have their own voices and are not only to be "spoken for" by adults. ${ }^{25}$

\section{Interests}

The interest, or benefit, theory of rights proposes that rights flow from essential interests. Children's interests have been classified as basic, developmental and autonomy interests, ${ }^{36}$ the scope and balance of which may differ from adults' interests ${ }^{37} 38$ (table 4). Adults with different perspectives on how to balance children's interests have been described $\mathrm{as}^{39}$ :

- parentalists, who think parents should decide for their minor children;

- interventionists, who think that, at times, professionals know what is in a child's best interests; and

- libertarians, who think children should have adult rights as soon as they are old enough to exercise them.

Decision-making about any minor's "best interests" involves parents, professionals and the child. Here, beliefs may clash. In contrast, the legal concept of "best interests" only applies to adults who lack capacity. Perhaps, when others are ascribed duties in relation to minors, who are defined as lacking the capacity to be responsible for themselves, it is "best duties" and not "best interests" that tip the balance. Arguably, the essential question is about autonomy rather than capacity or competence; many children and young people would have the capacity to be responsible for themselves, if they were legally, politically, economically and socially permitted and enabled, for example if they had adult rights.

\section{Orientation}

Different groups of people have different attitudes or beliefs in relation to children's rights. These attitudes are sometimes referred to as orientations in the rights literature. Some, having a nurturance orientation, believe that children's rights are based on their particular welfare and protection-related needs. Those with a self-determination orientation prioritise children's choices over their parents' in relation to decisions about the child..$^{29} 40$
The two orientations can co-exist if the question of age is removed, ${ }^{29}$ however:

- practically, tests of capacity for responsibility for oneself are difficult to establish; capacity is therefore often ascribed by status, for example adulthood, defined by age;

- it is important to promote the wellbeing of children, as a group of people; children are in their childhood, again most commonly defined by age.

The public health agenda of promoting the health of children, as a group of people, can be pursued using the concept of human rights: to protect and provide for children (as a vulnerable group) and give them negative rights (as an oppressed population) and participation rights (as a disempowered minority). ${ }^{41}$ Public health, however, is communityrather than individual-orientated and bias towards health benefit for the wider population of children over respect for individual autonomy or choice is inherent, ${ }^{42}$ for example it has more of a nurturance than a self-determination orientation.

\section{Being part of a family}

The interests, or value, of being part of a family seem more often ascribed to children than adults. Many Western philosophies of ethics, law and politics are based on the individual. The "child" is, in contrast, a concept rooted in contexts of relationships with parents, family and society. The family is accepted as the natural and most successful unit/environment within which to bring up children. ${ }^{43}$ This view informs the law, ${ }^{3}{ }^{4}$ contemporary human rights documents, ${ }^{44}$ and professional $^{45}$ and institutional ${ }^{46}$ guidance.

\section{Child-specific laws and conventions}

The $\mathrm{UNCRC}^{44}$ is referenced by almost all contemporary resources on children's rights. The four core principles of the convention are:

- non-discrimination,

- devotion to the best interests of the child,

- the right to life, survival and development, and

- respect for the views of the child.

The preamble to the convention explains that:

- these rights are in accordance with inherent human dignity,

- childhood entitles one to special care and protection, and

- the family is the fundamental group of society and the natural environment for the growth and wellbeing of all its members and particularly children.

The UK Government ratified the UNCRC in December 1991 and is obliged to develop and undertake all actions and policies in the light of the best interests of the child. The tenets of the UNCRC underlie the Children Act 1989 and NHS policy. ${ }^{46}$

Table 4 Similarities and differences between children's and adults' interests

\begin{tabular}{|c|c|c|}
\hline Type of interest & Similarities & Differences \\
\hline Basic interests & $\begin{array}{l}\text { Common interest in general physical, } \\
\text { emotional and intellectual wellbeing }\end{array}$ & $\begin{array}{l}\text { The level of care that can be expected from others (whether from significant } \\
\text { others/parents/carers or the state and its agencies) may differ because of } \\
\text { differing levels of vulnerability, ability or responsibility to care for oneself. }\end{array}$ \\
\hline Developmental interests & $\begin{array}{l}\text { Common interest in maximising } \\
\text { one's potential }\end{array}$ & $\begin{array}{l}\text { The emphasis on promoting children's developmental interests, so that they } \\
\text { reach adulthood disabled as little as possible by the circumstances of their } \\
\text { family or personal difficulties, leads to claims over and above the claims of } \\
\text { adults, who are expected to promote their own developmental interests. }\end{array}$ \\
\hline Autonomy interests & Common interest in choosing for oneself ${ }^{37} 38$ & Adults are cautious about giving children the right to make their own mistakes. \\
\hline
\end{tabular}




\section{Box 1 Helpful questions}

When faced with a rights-based dilemma in practice, asking the following questions may aid justified action:

- How many types of relationship are pertinent to my interaction with this child and his/her parents?

- How many categories/types of rights are relevant to these relationships?

- What is the justification for each type/sort of right? (When considering the child's interests, consider basic, developmental and autonomy interests.)

- What duties or responsibilities correlate with each of these rights and which of these do I hold?

- Who else has rights in relation to this situation?

- Which rights are absolute and which are proportionate. (If proportionate, to what degree?)

- What other legal, moral, socio-cultural and political principles or values are important?

- What interests or rights am I going to prioritise and why?

If your reasoning leads you to an action you are reticent to undertake:

- is this because there are factors that make acting in this way difficult, for example:

- your personal morals clash with the law on this matter and you must decide which to prioritise,

- your professional role morality clashes with your role as a public servant and you must decide which to prioritise and take the consequences,

- your interpersonal skills may be challenged by the process of communicating your decision or reasoning leg, I do not know how to contain the sadness and anger the child's parents will feel),

- as a person, you will find it hard to bear the feelings associated with the consequences of your action (eg, I cannot bear the sadness of knowing this child will die as a result of my decision), or

- is this because your reasoning is incomplete or inconsistent?

Other statutory legal rights vary. While the Mental Health Act 1983 refers to patients of any age, age-specific legislation is applied to criminal justice and education. The effects of the HRA on children's rights in the UK are not yet significant but are leading to the re-emergence of parents' rights $^{47}$ (to privacy and family life) as opposed to parental duties (described as parental responsibilities under the Children Act 1989²). Children have rights as service users ${ }^{46}$ but their engagement in this role is less frequent than that of adults.

Different advocates of "children's rights" may have different perspectives or orientations. Stating that one promotes "children's rights" means more when there is clarity about:

- which categories of rights are being prioritised,

- who holds the primary duties/responsibilities and why, and

- whether the interests of individual children or of children as a category of people are being promoted.

\section{PRACTICAL IMPLICATIONS}

Paediatricians have to manage the tension between being childcentred, supporting parents and families and being employed as experts in their field to deliver healthcare to service users. This means that they have roles and duties in relation to individual patients (children and young people), their families (their parents in particular), their profession (as members of the RCPCH and regulated by the GMC) and the delivery of government policy in relation to children and children's public health. They also have their personal values and morals and are subject to the law as it relates to them as individuals and healthcare practitioners. This requires them to:

- consider moral, legal, political and socio-cultural rights simultaneously,

- balance individualist/libertarian, parentalist and interventionist perspectives with regard to children's rights, and

- balance their duties to their child patient with duties to:

- children as a group of people,

- the child's parents,

- their employer and the government, and

- their professional peers and their profession.

Ultimately, a number of ways of acting in relation to children and their rights may be justifiable. Justification is, however, dependent on clarity about what types and categories of rights are being deployed, what is meant by childhood and honesty about how we decide to act as individuals (box 1).

The RCPCH embraces paediatricians' roles as advocates for children, acting in their child patients' best interests and promoting the public health of children as a group. The inherent tensions in such obligations include:

- problems applying the concept of "best interests",

- knowing that hearing children's views and facilitating their participation in decision-making does not equate with children having the last say in matters concerning their health, and

- the need to balance

- children's rights with their parents' rights $^{48}$ and

- individual children's needs and interests with public health concerns about the needs and interests of children as a group, especially when healthcare is delivered by publicly-accountable services with finite resources, to which issues of distributive justice and rationing apply. ${ }^{49}$

Using a rights approach therefore supplies alternative ways of reasoning about clinician's actions but does not necessarily reduce tensions encountered when applying other ethical, legal and political theories. Using a rights framework has provided a practical way of pursuing a public child health agenda and addressing inequity in children's health, especially at a global level. ${ }^{41}{ }^{50-52}$

What remains unclear is the part played by professional role morality in individual paediatricians' decisions and what orientation most paediatricians have to children's rights. Evaluation, before and after the implementation of new college programmes, will indicate how successful the RCPCH's children's rights-based stance is in influencing paediatricians' practice and role morality.

\section{CONCLUSION}

Variability in the meaning of rights and children's rights implies that, in any discussion about "children's rights", the 
type, category, justification, scope and limits of what is meant by rights should be explicit. Paediatricians' have many duties in relation to children's rights and sometimes they may conflict. Using a rights framework may be more useful in addressing public child health than reducing dilemmas related to clinical practice.

\section{ACKNOWLEDGEMENTS}

I am grateful to Doug Simkiss, Peter Sidebotham and Heather Draper for their comments on this paper.

\section{Funding: None.}

Competing interests: The author is a member of the Warwick Equity \& Children's Rights Research Group, which is the UK research arm of the RCPCH/AAP Equity Project.

\section{REFERENCES}

1 Almond B. Individual rights in the health care relationship. In: Gillon R, eds. Principles of health care ethics. Chichester: Wiley, 1994:511-18.

2 Paul M, Newns K, Creedy KV. Some ethical issues that arise from working with families in the National Health Service. Clin Ethics 2006;1(2):76-81

3 Children Act 1989. London: HMSO.

4 Human Rights Act 1998. London: The Stationary Office).

5 Beauchamp T, Childress J. Principles of biomedical ethics, 4th ed. New York: Oxford University Press, 1994.

6 Haji I, Cuypers S. Moral responsibility, love and authenticity. J Soc Philos 2005;36(1):106-26.

7 General Medical Council. Good medical practice. London: GMC, 2006, Available from http://www.gmc-uk.org (accessed 16 February 2007).

8 The Royal College of Paediatrics and Child Health. Duties of a paediatrician. Available from http://www.rcpch.ac.uk/about/duties.html (accessed 16 February 2007).

9 Ekman Ladd R. Rights of the child: a philosophical approach. In: Alaimo K, Klug B, eds. Children as equals. Lanham: University Press of America, 2002;89-102.

10 Archand D, Macleod CM. The moral and political status of children. Oxford: Oxford University Press, 2002.

11 King M, Trowell J. Children's welfare and the law: the limits of legal intervention. Newbury Park, CA: Sage, 1992.

12 Kennedy I. Treat me right. Oxford: Clarendon Press, 1988.

13 Montgomery J. Health care law, 2nd ed. Oxford: Oxford University Press, 2003.

14 Edgeworth B. Law, modernity, postmodernity. Aldershot: Ashgate, 2003.

15 Penner J, Schiff D, Nobles R. Introduction to jurisprudence and legal theory. London: Butterworths, 2002.

16 JUSTICE. A guide to the Human Rights Act 1998. Questions and answers. 2000 Available from http://www.justice.org.uk/images/pdfs/HRAINT.PDF (accessed 16 February 2007).

17 Swidells H, Neaves A, Kushner M, et al. Family law and the Human Rights Act 1998. Bristol: Family Law, 1999.

18 Fortin J. Children's rights and the developing law. London: Butterworths, 1998.

19 Bainham A. The balance of power in family decisions. Camb Law J 1986;45(2):262-84.

20 King M, Piper C. How the law thinks about children. Aldershot: Arena, 1995.

21 Ingram A. A political theory of rights. Oxford: Clarendon Press, 2002.
22 Douzinas C. The end of human rights. Oxford: Hart Publishing, 2000.

23 Beyleveld D, Brownsword R. Human dignity in bioethics and biolaw. Oxford: Oxford University Press, 2001.

24 Brems E. Children's rights and universality. In: Willems J, eds. Developmental and autonomy rights of children. Antwerp: Intersentia, 2002;21-45.

25 John M. Children in charge. The child's right to a fair hearing. London: Jessica Kingsley, 1996.

26 Alaimo K, Klug B. Children as equals. Lanham: University Press of America, 2002.

27 James A, Prout A. Constructing and reconstructing childhood. London: Falmer Press, 1997.

28 Gatrell C. Hard labour: the sociology of parenthood. Maidenhead: Open University Press, 2004.

29 Franklin B. The new handbook of children's rights. London: Routledge, 2002.

30 Hall D. Children, rights and responsibilities. Arch Dis Child 2005;90:171-3.

31 Wheeler R. Children's rights. Arch Dis Child 2005;90:174-5.

32 Brook G. Challenges and outcomes of working from a rights based perspective. Arch Dis Child 2005;90:176-8.

33 Waterston T. A general paediatrician's practice in children's rights. Arch Dis Child 2005:90:178-81.

34 Waterston T, Mann N. Children's rights. Arch Dis Child 2005;90:171.

35 Alderson P. Rights of children and young people. In: Coote A, eds. The welfare of citizens.Developing new social rights. London: IPPR/Rivers Oram Press, 1992;153-80.

36 Eekelaar J. The emergence of children's rights. Oxford J Legal Stud 1986;6(2):161-82.

37 Alderson P, Montgomery J. Health care choices: making decisions with children. London: Institute for Public Policy Research, 1996.

38 Dickenson D, Jones D. True wishes: the philosophy and developmental psychology of children's informed consent. Philos Psychiatry Psychol $1996 ; 2(4): 287-303$.

39 Alderson P. Children's consent to surgery. Buckingham: Open University Press, 1993.

40 Freeman MDA. The rights and wrongs of children. London: Frances Pinter, 1983

41 Waterston T. Inequity in child health as a global issue. Pediatrics 2003;112(3):739-41.

42 Kass NE. An ethics framework for public health. Am J Public Health $2001 ; 91(11): 1776-82$.

43 Bidwell L, Vander May B. Sociology of the family: investigating family issues. Boston, MA: Allyn \& Bacon, 2000.

44 UNICEF. Convention on the Rights of the Child. Available from, http:// www.unicef.org/crc/crc.htm (accessed 16 February 2007).

45 British Medical Association. Consent, rights and choices in health care for children and young people. London: BMJ Books, 2001.

46 Department of Health. National service framework for children, young people and maternity services. London: Department of Health Publications, 2004.

47 Hagger L. The Human Rights Act 1998 and medical treatment: time for re examination. Arch Dis Child 2004;89:460-3.

48 Lansdown G. Implementing children's rights and health. Arch Dis Child 2000;83:286-8

49 Lenaghan J. Hard choices in health care. London: BMJ Publishing Group, 1997.

50 Goldhagen J. Children's rights and the United Nations Convention on the Rights of the Child. Pediatrics 2003;112(3):742-5.

51 American Academy of Pediatrics. The Equity Project. Available from http:// www.aap.org/commpeds/international/equity.html (accessed 16 February 2007).

52 Goldhagen J, Waterstone T. Conclusion: The Equity Project. Pediatrics 2003;112(3):771-2.

\section{BNF for Children 2006, second annual edition}

In a single resource:

- guidance on drug management of common childhood conditions

- hands-on information on prescribing, monitoring and administering medicines to children

- comprehensive guidance covering neonates to adolescents

For more information please go to bnfc.org 